\title{
STERILITY IN THE LARGER DOMESTICATED ANIMALS:*
}

\author{
By EUGEN BASS, Veterinary Surgeon, Kranichfeld.
}

THE abnormalities of the sexual apparatus of our domesticated animals, and their influence on the reproductive power of the latter, is a subject that, in veterinary literature, receives little attention, and is therefore somewhat obscure. How often do we hear complaints regarding the sterility of mares and cows, and how slight is our knowledge of its cause! On that account it appears desirable that we veterinary surgeons should concern ourselves more than has hitherto been the custom, with this part of veterinary pathology, in order to throw a clearer light on the subject, and to be able to help to diminish the losses which result to stock-owners through our want of knowledge. In the following pages an attempt will be made, partly on the ground of personal experience, partly by the aid of what has already appeared in literature, and also with the help of the recorded observations regarding the same conditions in the human subject, to give a stimulus to further researches regarding this still neglected branch of veterinary science.

Since the fusion of the sexual products of the male and the female animal is necessary for the production of a new being, the causes of sterility in our domesticated animals also are to be sought in the three conditions which Courty $\dagger$ holds accountable for sterility in woman, viz., (I) inability to perform coitus, (2) inability to fertilise, and (3) inability to form the reproductive cell (ovum or spermatozoon), and these defects may be on the side of either the male or the female animal. On that account it will be best to arrange the following article so that the causes which induce sterility on the side of the sire will be considered under $A$, while infertility on the side of the dam will be discussed under B. Each division will in turn allow of several sub-divisions, according as the cause of the sterility is to be sought in morbid conditions, or in defects in the mode of using and keeping the animals in question, which determine a permanent or a temporary existence of the infertility.

\section{A. THE CAUSE OF THE NON-FERTILISATION IS IN THE SIRE.}

\section{a. Inability to perform coitus.}

The act of procreation is possible only when the sexual organs are present in normal form and shape, and when the penis can be introduced in the erect condition into the sexual organs of the female. All those conditions which make the introduction of the penis into the vagina impossible, as well as all morbid processes that hinder the occurrence of normal erection of the male penis, whether these be either permanent or temporary, give rise to impotentia coeundi.

Under the first group of abnormal conditions there are included, in the first place, tumours on the penis, curvatures of the same as a result of cicatricial formation after wounds, and congenital deformities, such, for example, as may be determined by certain cases of

* Translated from the Dentsche Zeitschrift fur Thiermedicin, March 1594.

+ A list of the authors quoted is given at the end of this article. 
hypospadisis; also tumours of the prepuce, which hinder the introduction of the penis into the vagina. To this group also belong defects in the attachment of the penis, adhesion or narrowing of the prepuce as a result of chronic inflammation, in consequence of which the protrusion of the penis is made impossible, and sometimes also inguinal and scrotal hernia, when these are of excessive size. There may also be included in this group all those painful conditions about the belly or in the abdominal cavity, wounds and inflammation of the penis, painful affections of the hind feet, such as spavin, laminitis, etc., which cause the animal to refrain from coitus in consequence of the pain induced by the act.

The second group includes those morbid processes which altogether prevent or admit only an incomplete erection of the penis, and these may have their origin in local conditions. Fracture or paralysis of the penis (the latter determined by paralysis of the dorsal nerves of the penis, by cutting which Guinther, Hausmann, and Colin could make erection impossible) lead to the loss of power to erect the penis, just like diseases of the lumbar part of the cord itself (which, according to Ellenberger, contains the special centre for erection), or like diseases of the brain, in consequence of which the sexual appetite is abolished, and stimulation of the before-mentioned centre does not take place. Then, as is well known, psychical excitement may induce erection of the penis. Hence we observe a loss of sexual appetite in horses suffering from chronic hydrocephalus. Onanism must also be reckoned here, for animals that are the subjects of this vice, after they have for a time indulged the morbid propensity, show incomplete power of erecting the penis, and cannot be brought to copulate with animals in oestrum, as we see in the case mentioned by Spinola. ${ }^{4}$

As regards therapeutics, it may be expected that whenever the cause of the impotentia coenndi can be combated the consequence of the disease will be only temporary; on this account treatment should be mainly directed towards the rational removal of the real root of the mischief. It should thus consist in operative removal of tumours, or in division of an adherent or contracted prepuce, and in overcoming painful conditions of the hind extremities. When the diseased conditions specified above have been successfully treated the morbid consequence-the sterility of the male-will be abolished; only in malformations, cicatricial contraction, and paralysis of the penis, will the sterility be absolute and permanent.

Fenner ${ }^{5}$ regards deficient erectile power in consequence of cicatricial contraction of ulcers on the penis as the cause of impotence in bulls after an attack of the so-called Bläschenausschlage (an eruptive infectious disease of the genitals).

Gallimore ${ }^{6}$ reports that after treating a fracture of the penis the end of the organ was no longer erected.

Gurlt ${ }^{7}$ describes the generative organs of a stallion that was the subject of hypospadisis, and possessed at the anterior end of the penis on both sides two flat muscles which fastened the penis to the anterior edge of the pubic bone. When, in presence of a mare, the penis of the stallion became erect, these muscles pulled the penis backwards and downwards, and thus made the act of coitus impossible.

Dietrich, ${ }^{8}$ in a very valuable ram that was unable to tup a ewe because it 
could not protrude the penis for more than $\mathbf{x}$ inch, and hence could not reach the vulva with the organ, found narrowing and adhesion of the prepuce, which hindered the protrusion of the penis. The animal was cured by a deep incision into the prepuce.

Spinola ${ }^{4}$ treated successfully, by division of the prepuce, a very valuable bull, which had suffered from ulceration of the prepuce, with consequent inability to copulate, and which even after recovery was still impotent because the orifice of the penis was so narrow that the penis could not be protruded.

Hering ${ }^{9}$ operated on a stallion which was unable to protrude the penis owing to a fold that had formed in the prepuce. Since the animal was not able to satisfy the sexual desire it was vicious towards both men and animals. After removal of the fold of skin the stallion was able to copulate freely.

Spinola ${ }^{4}$ mentions that a two-year-old bull actively practised masturbation, but left cows in cestrum unbulled.

Piovesan ${ }^{104}$ removed from a stallion a fibro-sarcoma as large as a child's head, which had its seat on the right side of the sheath and reached from the preputial orifice to the testicles.

Hobday ${ }^{105}$ operated on a pony stallion which had under and partly around the penis a fibroma that hindered retraction.

Miller ${ }^{106}$ observed a case of phimosis in a bull, in which the prepuce was firmly united to the penis, with inability to copulate as a consequence. The bull was fit for service after the adhesion had been divided.

\section{b. Inability to Impregnate.}

All the sexual organs may be normally developed, the penis may be erected, and the act of copulation performed, and yet impregnation may not take place. The cause of this may be absolute inability to ejaculate the semen, or failure of the semen to reach its destination, or, lastly, some abnormality in the spermatozoa, such as is the case, according to Fürbringer's ${ }^{10}$ observations, when the prostatic juice is absent or altered. In consequence of the abnormal character of the prostatic secretion the spermatozoa become rigid, and thus lose their fertilising power. The prostatic juice, together with the secretion of the other accessory glands of the male, viz., the vesiculæ seminales and Cowpers glands, make possible and actively excite the motility of spermatozoa. The impotentia generandi may thus co-exist with full potentia coendi.

If the inability to fertilise is due to the fact that the seminal fluid cannot be discharged from the sexual organs, the condition is designated aspermia, or aspermatismus. Among the processes that make the escape of semen impossible, and which can induce aspermia, there may be mentioned malignant tumours on the penis, which narrow the urethral orifice; swellings, strictures, and obliterations at some part of the mucous membrane of the uro-genital tract, the former brought on by acute inflammation, the latter as the result of chronic infectious inflammations. In human pathology, and according to Zundel and Semmer in veterinary pathology also, sharp bends and twists of the vas deferens from abnormal position of the testicle are a further but only occasionally observed cause of aspermia; this is the so-called inversio testis, of which one recognises anterior inversion when the free part of the testicle lies behind and the epididymis in front, lateral inversion when the epididymis is turned outwards or inwards, and horizontal inversion when the testicle is so twisted on its apex that the hinder end lies anteriorly. 
Concerning the diagnosis of such conditions, it is obvious that only an accurate local examination (such as rectal examination in sterility due to prostatic disease) can afford certain information.

In the treatment of aspermia the prognosis and results depend upon whether the cause is removable or not. A favourable termination may as a rule be expected in the case of tumour formations and acute inflammations, but only exceptionally when the narrowing of the urethra is caused by chronic inflammation.

Among the conditions that prevent the seminal fluid from reaching the vagina, in spite of proper introduction of the penis into the genital passage of the female, is hypospadias-that arrest of development in which the posterior under wall of the urethra, at any place between the glans penis and the bladder, is not closed. The defect may be in the glans, the pendulous part, or the scrotal part, and in consequence of it the seminal fluid does not gain the vagina of the female animal, but flows outwards from the vulva.

In Lavirotte's ${ }^{11}$ case the penis of a bull was covered with papilloma, and all the cows served by this animal remained sterile. When the cows were slaughtered on this account the interior of the sexual organs was found to be covered with similar vegetations. The papillomata on the bull's penis were excised and cauterised, and various cows subsequently served by him became pregnant. May not the presence of the papillomata have hindered or altogether prevented the exit of the semen?

Huickman operated on a bull which was unable to serve cows owing to a tumour on the penis. The operation was successfully yerformed, and the bull was again fit for service.

According to Gurlt's ${ }^{13}$ view the non-discharge of semen may be due to (r) narrowing of the pelvic part of the urethra, and (2) to the presence of abscesses in the abdominal cavity.

\section{c. Inability to form Semen.}

Aspermia is not the only cause of impotentia generandi, for that may be determined by absence from the semen of the spermatozoa necessary for the act of procreation. That condition is termed azoospermia. All those processes that hinder the formation of spermatozoa induce azoospermia, and the causes, and therewith the condition itself, may be permanent or only transitory. In the former case one speaks of absolute azoospermia, in the latter of relative azoospermia. All those processes which lead to destruction and shrinking of the glandular tissue of the testicle are at the root of the absolute azoospermia, while defects in the food or manner of keeping the animal as a rule only temporarily diminish the activity of the testicular tissue, and hence cause only the relative azoospermia. When once these latter causes have been overcome, then in most cases the evil which results from them also disappears, provided that the changes induced by them in the tissue of the testicle have not advanced so far as to render the formation of spermatozoa altogether impossible.

Among the conditions that lead to absolute azoospermia, apart from complete absence of the testicle (anorchismus), are: destruction of the testicle from malignant tumours, or by acute chronic or inflammatory processes with consequent purulent softening, fatty degeneration, local gangrene of the testicular tissue, proliferation of the 
interstitial tissue, with subsequent sclerosis, calcification, or ossification of the same (as has been observed in the horse, bull and ram $^{39}$ ), followed by atrophy of the secretory part of the gland tissue. As a rule the retention of the testicles in the abdominal cavity or in the inguinal canal (abdominal and inguinal cryptorchismus) has the same effect. In these conditions the testicles are in most cases in a state of fibrous degeneration, atrophic, flabby, and not in a condition to produce spermatozoa; it is only exceptionally that a testicle which remains in the abdominal cavity is observed to have a normal character, and the cryptorchid to have unimpaired reproductive power. Hydrocele, or the accumulation of serous transudate or exudate in the tunica vaginalis, which presents itself as a non-painful fluctuating swelling of the scrotum, and is always the result of inflammation or irritation of the serous membrane, can by pressure of the serous fluid give rise to atrophy of the testicle, and through that at first to a relative, or if the condition persists to an absolute, sterility. Spermatocele, which develops in consequence of a proliferation of the connective-tissue, with subsequent accumulation of semen in the seminal canals of the testicle, and cystic dilatation of the latter, may have the same result, in consequence of the pressure exerted by the marked over-growth of the connective-tissue in the neighbourhood of the cysts. A similar effect can be produced by varicocele or circocele, which is a varicose dilation of the veins of the spermatic cord, testicle, and epididymis, determined by congestion; for, in consequence of the impeded overflow of blood from the veins, fatty degeneration of the semeniferous tubes, proliferation of the connectivetissue, and atrophy of the parenchyma of the testicle are determined. Sometimes inguinal and serotal hernia act in the same way and with the same result. Hence in old inguinal hernias the testicles appear atrophied and flabby.

It still remains to be mentioned that of tumours in the testicle, besides cysts, the fibroma, the dermoid, the carcinoma, and also tuberculosis have been observed.* Lastly, it ought not to be passed over with silence that longstanding chronic diseases, through defective nutrition of the testicle, lead to atrophy of that organ, and thus to temporary or permanent infertility in the male.

In all those repeatedly observed cases of sterility in hybrids and male twins, in which there is no recognisable cause, it must be assumed that there is some abnormal character in the tissue of the testicle. That in these cases the sterility frequently has its cause in fatty degeneration of the testicles, may be inferred with some justification from the results of the observations made at Halle in the case of the infertile yak hybrids.

In a case of twin bull calves which came under my own notice in Steinau I observed that one of the animals was capable of service and gave proof of its efficiency, while the other showed not the least trace of sexual appetite, although the generative organs were apparently normally developed. The statement of Rueff, that the Dutch on account of probable sterility do not use bull calves with strong hind quarters (cul de cheval) for breeding, deserves to be mentioned at this place.

* It may here be remarked that no animal ought to be declared fit for breeding whioh has not by previous inoculation with tuberculin been found free from tuberculosis. 
Among the causes of relative azoospermia, food and management of male animals undoubtedly play a prominent rôle. Either too little or too much food has an injurious effect on the reproductive power of the male animal. Either a fattening diet or niggardly feeding may induce sterility in the male. By excessive feeding with fattening articles of diet, usually reinforced by lack of light, air, and exercise, a general increase of fat and also a fatty degeneration of the semenproducing parts is brought about, while, on the other hand, an insufficient diet has for consequence a loss of the general vigour of the body, a diminution of the reproductive power, and possibly also a change of the seminal fluid in quantity and quality. Even in cattlebreeding the correctness of the proverb of Horace regarding the aurea mediocritas may be plainly recognised.

How great is the influence of diet on the fruitfulness of male animals is proved by Fogliata's ${ }^{15}$ observations, which show that green food increases the fertility of the stallion, while dry and stimulating articles of diet have the opposite effect; the relative effect of the two being as 70: IOO, and in some cases 50: Ioo. Viseur ${ }^{16}$ also confirms the injurious effects which an excessive diet exerts on the sexual organs of male breeding animals. These become docile and quiet after feeding for weeks on cut food and oil cake, and with the inactivity of the testicles the flesh even loses the peculiar strong flavour which belongs to it when the productive organs are normally developed. A further confirmation of the correctness of this opinion is furnished by Damman, ${ }^{17}$ who says that by feeding stallions exclusively with maize the sexual appetite is diminished, and the same effect is produced by the addition of barley to oats; while, on the contrary, a daily addition of 2 to $4 \mathrm{lbs}$. of peas and beans excites the sexual appetite, and increases the seminal secretion in stallions.

The observation may frequently be made that when a number of female animals are put shortly after one another to the same male only a part of them conceive, although the blame for this cannot be laid on the females. Where does the defect lie here? Just in the management of the animals, and in the deficiency of the semen in spermatozoa which is determined by bad management-in other words, in the relative azoospermia. According to Colin, ${ }^{2}$ at the end of the act of coitus, when the genital spasm has reached its highest point, the seminal fluid is ejaculated in greatest quantity, whereas the prostatic fluid escapes at an earlier period. Now, since the semen is only slowly renewed, it follows that when many mares or cows are brought for service on the same day to one and the same male, at the fifth or sixth act of coitus no semen, but only prostatic fluid, will be ejaculated, and hence the infertility of the last females served. According to Casper, ${ }^{18}$ a temporary azoospermia is produced in man himself, even in individuals otherwise healthy and capable of procreation, by the too frequent practice of coitus. On account of its interest, it may here be further mentioned that, according to Haussmann, ${ }^{19}$ it was directly observed by Casper that the semen discharged by one and the same man contains at one time many and at another no spermatozoa, and that Mantegazza ${ }^{19}$ has by microscopic examination proved the depend. ence of this variation on the frequence of cohabitation. This fact, as Haussmann also mentions, was even known to Susruta. The passage referring to this by Susruta, according to Haussmann, is: "A viro 
coitum exercente primum (semen) prævalet; a viro autem ultra modum coitum exercente alia femina semen virila sæpius non concipit."

The accuracy of the opinion expressed by Colin and Mantegazza has been made evident to me by numerous observations made in practice. The following may serve as proof. In the part of the Grand Duchy of Weimar adjoining my official district, and in which I practice, at many places $\mathrm{I} 20$ or more cows and queys are put to one bull, so that a bull in one day has sometimes to serve five, six, or more cows. The people frequently complain to me that their cows do not conceive, and ask my advice in the matter. The advice which I give them is to provide an additional bull, as the number of cows is too great for one. As proof that in the district in question this is in most cases the cause of the barrenness of the cows, I always refer the farmers to the neighbouring district of Meiningen. Here not more that seventyfive cows and queys are put to one bull, and there is no complaint that the cows must be taken three or four times to the bull, as is so often the case in the adjoining district of Weimar. Another circumstance that operates adversely is that in many cases too young bulls are used. Thus in the Weimar district bulls are put to service as early as the age of fifteen months, while in the Meiningen country the lowest age is eighteen months, and that in my opinion is even too young for the Simmenthal-Frank cross, which is the breed here used. How can an animal be expected to propagate and transmit its peculiarities when it has not yet itself reached its full development !*

Fuchs ${ }^{20}$ goes to the root of the matter when he says: "when in many places people are content to reckon one such bull as sufficient for IOO or more cows (and this rule is not always conformed to by the parishes), it is not to be wondered at if in numerous districts cattlebreeding is declining, and the sterility of cows increases more and more, How can one expect such a bull to successfully discharge his functions when one reflects that our cows and heifers, although at all seasons in cestrum and capable of becoming pregnant, are nevertheless by the owners arbitrarily put to the bull only at certain times of the year (generally in spring and autumn, in order that they may calve at the beginning of winter or in spring), so that the services of the bull for a short period of the year are in excessive demand, and the animal is left in a state of inactivity for the greater part of the twelve months."

Turning now to the diagnosis of male sterility, a thorough examination of the generative organs must be made by a qualified person, but, on account of the azoospermia, a special value attaches to a microscopic examination of the seminal fluid, the importance of which as an aid to diagnosis cannot be too strongly recommended. Although in veterinary literature only a few cases of azoospermia are recorded, it may nevertheless with some justification be assumed that this condition is just as frequently a cause of sterility in animals as it is in the human species, in which Kisch found azoospermia of the male as the cause in 9 per cent. of the cases of female sterility investigated by him. It is certainly the case that in veterinary practice one hardly ever thinks of examining the seminal fluid of the male for the presence

* Professor Johne says that all veterinary surgeons who have had experience of the system of having parish bulls must have made the same observation. 
of spermatozoa, although the examination is quite simple, consisting merely in transferring to an object glass a little of the fluid that drops from the meatus urinarius after coition (when the male has dismounted), and examining this microscopically without the addition of anything. Observations made in practice prove that azoospermia is by no means so seldom an occurrence as is generally supposed. How otherwise could one explain cases in which one bull serves several hundred cows without impregnating one of them? What a pecuniary loss is caused in this way! In order to prevent these untoward occurrences we veterinary surgeons ought to make it our duty, in all cases in which a male animal has unsuccessfully served a large number of females, unless there is other satisfactory evidence of the animal's reproductive power, to at once examine the semen for the presence or absence of spermatozoa.

On microscopic examination of the seminal fluid, which is a mixture of the secretion of the testicle with that of the accessory glands, we find in it, besides epithelium and spermatoblasts, the spermatozoa, which, unless they are dead, exhibit a peculiar active movement. This motility of the spermatozoa may be stimulated or abolished by the action of various substances. Thus their movement is markedly excited by the secretion of the accessory reproductive glands of the male, the cestral mucus from the vagina of the female, and moderately concentrated alkaline solutions, whereas they become paralysed or killed by the action of water or acid secretions. It is important to notice here that even in the case of dead or no longer motile spermatozoa, one can tell by microscolic examination whether they were dead before they left the testicle or perished after the ejaculation of the semen. In the former case the tail of the spermatozoon is rolled in a spiral or shows short bends, whereas in the latter it is straight.

The therapeutics of azoospermia must depend upon the conditions present. Absolute azoospermia is incurable, whereas in relative azoospermia it may be possible to get good results by a change in the general management of the animal. In the azoospermia caused by the presence of a dermoid one might, following Hoffmann's ${ }^{10}$ recommendation, excise, with antiseptic precautions, wedge-shaped pieces of the testicle, after the method of Maffuki; after two months a tubular tissue resembling the parenchyma of the testicle develops in the cicatrices, and by this means the production of spermatozoa becomes possible. In hydrocele also, according to Hoffmann, ${ }^{10}$ a piece of the thickened tunica vaginalis may be excised, with antiseptic precautions, after which the wound must be very carefully sutured with catgut, drained, and covered with a dressing. In these ways it may occasionally be possible to successfully treat cases of relative azoospermia caused by hydrocele, so long as the condition has not become absolute. It is questionable whether as favourable results might not be obtained by drawing off the fluid with a trocar and then injecting tincture of iodine, ${ }^{30698}$ that is, of course, always providing that the azoospermia has not yet become absolute.

Fabricins ${ }^{21}$ examined a stallion, fourteen and a half years old, which had been bought for stud purposes, and which for four years previously had been employed to serve mares in the country, and he found, on microscopic examination, not a single spermatzoon in the animal's seminal fluid; on further inquiry it was ascertained that the stallion had not got a single foal during the previous two years of his service in the country. 
Leisering ${ }^{6}$ examined the testicles of a stallion that had unsuccessfully covered forty mares, and found them of almost normal size, but flabby and lacking the tense feeling of the normal organs; their arteries were dilated, the connective-tissue thickened, and the semen watery and transparent, with only a few spermatozoa but many round cells.

Rueff ${ }^{1 t}$ repeatedly observed infertility of male twins. In one case a twin bull served over roo cows without getting a single calf.

Brüller ${ }^{22}$ reports a case in which a twin bull calf proved impotent.

Louis mentions a similar case. A twin bull, whose testicles were normally developed, for several years served over 200 cows without getting one of them in calf.

Hartmann ${ }^{26}$ describes an interesting case of the sterility so frequently observed in cryptorchids; a cryptorchid boar ran round the sows, erected the penis, and introduced it into the vagina, but did not impregnate. When the animal was slaughtered it was found that the right testicle, normal in appearance, was situated behind the kidney, while the left lay as a bean-sized fleshy body in the flank. Spermatozoa could not be recognised on microscopic examination.

The cryptorchid stallion "La Cloture," notwithstanding that he showed no testicles, was bought for stud purposes, and in Pompadour covered forty mares without getting a single foal..$^{100}$

Roloff reports a case of suppuration of both testicles in a yearling ram, which, on account of this affection, was unfruitful.

In Damman's ${ }^{26}$ case of cystic myxosarcoma of the testicle in an old ram, it is not said whether the animal was sterile or not, and Herr Glokke of Falkenberg, who had sent the testicle in question to Damman, unfortunately could not give me any definite information on the point.

With respect to the sterility produced by some defect in management, Gabarret ${ }^{27}$ mentions that the use of one bull to serve too large a number of cows (1 50-200) induces sterility of numerous cows and heifers.

Fassler ${ }^{28}$ mentions that, in consequence of the system of having all the cows to calve as nearly as possible about the same time, the bulls have to serve an inordinate number of cows at one time, and therefore have to be highly fed, with the result that many cows remain barren.

\section{B. THE CAUSE OF NON-CONCEPTION IS IN THE DAM.}

\section{a. Inability to perform Coitus.}

This may have for its cause adhesions of the vulva, abnormally small dimensions of the vagina, excessive development of the clitoris, or altered position of the vulva, which in old lean cows loses its vertical position, and takes up an oblique or almost vertical direction. This is owing to the uterus sinking in a marked degree, just as it does shortly before the end of pregnancy; and thus exciting strong traction on the posterior pelvic wall (diaphragma urogenital pelvis) and the sacro-sciatic ligament (ligamentum tuberoso-et spinoso-sacrum), and pulling the vulva well forwards into the pelvis, as had already been pointed out by Anacker ${ }^{29}$ before Schünhoff. ${ }^{: 0}$ In consequence of any of these departures from the normal character of the female generative organs, the introduction of the male penis may fail to take place. We observe further that, just as in the male animal painful conditions of the penis may make the act of coitus impossible, so female animals will not allow the male animal to copulate with them when wounds or ulcers are present in the vulva or anterior part of the vagina.

The conditions specified may easily be diagnosed by an accurate 
manual examination, assisted when necessary by the aid of the vaginal speculum. Instead of the dear and somewhat cumbrous vaginal speculum of Polansky, it is preferable to employ Schlek's method of examination, which is as follows: While the vagina is dilated with the two hands of the person making the examination, an assistant holds the ordinary reflector with concave mirror, or any small lamp between the examiner's arms, and thus illuminates the interior of the vagina. The use of one of these two methods of examination is strongly to be recommended in every case, since it is only in this way that a complete survey of the vagina as far as the os uteri can be obtained.

Treatment of this condition is obviously only possible when the cause can be overcome. Adhesions must be severed with the knife, and when the clitoris is too large it must be removed. According to Schünhoff the inability to perform coitus caused by abnormal position of the vulva may be overcome by having the cow, in the act of bulling, placed with the hind quarters as low as possible, and by irrigating the vagina with a quarter per cent. solution of common salt before the cow is put to the bull.

In a ten-months-old quey'Knoll ${ }^{32}$ observed in place of the vulva two small fistulous openings, the upper of which led into the vagina, and the lower into the urethra; the urine was passed with difficulty. Knoll slit up the two canals, united them, and made two lips to the vulva; the hæmorrhage was profuse, and required the hot iron. The animal was subsequently bulled, but without result; apparently the uterus was absent.

Giese $^{6}$ in a year-and-a-half-old filly found an adhesion of the vulva, from its upper commissure to near the clitoris, and leaving only an opening of the calibre of a goose quill, from which the urine was discharged in a thin stream. Repeated incision of the adhesion was successful.

The Veterinarian ${ }^{: 3}$ for November 1849 contains a report regarding a quey that could never be bulled owing to the narrowness of the vagina.

Goubin ${ }^{34}$ observed in the case of a mare, in which the penis of the stallion had penetrated the rectum instead of the vagina, that the latter was remarkably narrow, so that not even the finger could be introduced.

Knowles ${ }^{35}$ found the vagina of a mare too short for copulation. Grognier also saw a case in which the vagina was so small as to make pregnancy impossible.

Hollmann, ${ }^{36}$ in the case of a mare that had repeatedly been in cestrum, found that the clitoris projected outwards for about half-an-inch between the lips of the vulva. After the clitoris had been extirpated the mare was covered, and became pregnant.

Dupont ${ }^{37}$ mentions as a not uncommon abnormality complete or partial adhesion between the lips of the vulva, as well as atrophy and hypertrophy of the clitoris.

Sanson ${ }^{38}$ in two Southdown sheep observed, besides other abnormalities, that the vagina had in its centre a string pierced by a canal, so that the penis could not be accommodated in it. It was only towards the meatus urinarius that the vagina was somewhat wider.

\section{B. Inability to Conceive.}

In the development of a new individual it is necessary that the male semen should meet the female ovum, which, according to Bonnet, as a rule takes place in the peripheral third of the Fallopian tube, or sometimes even at the ovary, while fertilisation of the ovum, 
in consequence of the changes that have already occurred in it, cannot be effected after its entrance into the uterus. Every circumstance that hinders this meeting of the semen with the ovum induces impotentia generandi, and the causes of this may lie in mechanical, chemical, anatomical, or physiological conditions, and be either congenital or acquired. Every arrangement in the female generative organs that hinders the access of the semen to the ovum acts exactly like the chemical causes, which by their reaction paralyse and kill the spermatozoa, and make their penetration into the ovum impossible. On this account, the causes of inability to conceive may be arranged under three subdivisions.

I. Mechanical Obstacles to Fertilisation.-Similar to the adhesions of the vulva, there are adhesions of the vagina, which may not make an emission from the penis impossible, but which nevertheless hinder a union of the two sexual products, and thus prevent fertilisation. As a rule these adhesions take the form of a membrane in front of the urethral orifice, often completely separating the vestibulum vaginæ from the vagina proper. In most cases such a membrane is an abnormally strong congenital development of the hymen, less frequently a cicatricial stricture formed in later life in consequence of a wound or ulceration. The same effect is produced by tumours in the vagina (lipoma, fibroma, myoma, carcinoma, etc.), chronic indurative inflammations of the os uteri and occlusions of the same by membranes or cicatricial tissue, as also by the vagina ending blindly with the uterus absent. In the same way the meeting of the semen with the ovum is made impossible by occlusion, narrowing, or swelling of the Fallopian tubes and their abdominal openings, such as have been observed in acute and chronic inflammation with consequent cicatricial stricture, or in tuberculosis of the Fallopian tube, or the presence of tumours, such as fibromata, carcinomata, sarcomata, melanomata, and cysts. Mechanical hindrance is also offered by displacements of the ovary, with consequent alteration of the favourable anatomical relationship between ovary and Fallopian tube, which make it possible for the ovum, when detached from the ovary, to be taken up by the surrounding fimbriated extremity of the tube. The result of such a displacement is that the ovum falls into the abdominal cavity, where it can neither be fertilised nor undergo normal development. Thus, for example, displacements into the perineum, as well as adhesion of the ovary with its surroundings, with consequent constriction and mechanical closure of the Fallopian tube, have been observed. The same effect on the Fallopian tube can be produced by curvatures and flexions of the uterus, either downwards (anteflexion and anteversion), or upwards (retroflexion and retroversion), or to the side (inflexio et inversio lateralis), - conditions that are of very rare occurrence in animals, and which, so far as I know, are mentioned by Semmer only. ${ }^{98}$ Lastly, as a mechanical obstacle to fertilisation, one must recognise occlusion or adhesion of the abdominal opening of the Fallopian tube in consequence of circumscribed peritonitis, and thickening of the covering of the ovary after inflammation, in consequence of which the ovum cannot reach the tube, or meet with the fertilising spermatozoa.

A certain diagnosis of these mechanical obstacles to fertilisation, which are discoverable at the post-mortem, often cannot be made not- 
withstanding the most accurate and careful examination; and one cannot hope to remedy such defects unless they are accessible to operative treatment; the latter, as will be seen from the following list of cases, can hardly be practised except when the mechanical obstacles to fertilisation are situated in the vagina or os uteri.

Degive $^{40}$ found an imperforate hymen in a foal. He encountered an unexpected resistance, in the shape of completely closed membrane, immediately in front of the meatus urinarius. When this was incised a considerable quantity of sticky, turbid, light grey fluid escaped-the secretory product of the vaginal mucous membrane.

Matthieu, ${ }^{40}$ in examining the vaginal canal of a twelve-months-old heifer, found a soft hemispherical tumour, which lay immediately behind the urethral orifice. The posterior wall of the tumour was composed of two membranes, of which the hindermost was incomplete, that is to say, it was perforated by two oval openings, separated from one another by a string. The anterior membrane, which was complete, was united to the middle string of the posterior one, and partly projected through the two oval openings of the latter.

Geyer ${ }^{107}$ observed in three queys occlusion of the vagina by a membrane, and when the latter was incised a turbid fluid escaped.

Schmidt-Herrieden ${ }^{107}$ in a two-and-a-half-years-old heifer found the vagina occluded immediately in front of the urethral orifice by a transverse partition, which was formed by the strongly developed hymen.

Gallier, ${ }^{41}$ in the case of a heifer that had been bulled six or seven times, and which strained severely but did not become pregnant, observed immediately in front of the meatus urinarius a membrane; when this was incised a large quantity of fluid flowed out, and the pains ceased.

Repiquet ${ }^{42}$ found in a cow a septum which began at the urethral orifice, and formed a hymen.

Cagny ${ }^{42}$ encountered in a mare a thick membrane which began in front of the urethral orifice, and almost occluded the vagina.

Leisering ${ }^{10: 3}$ saw a mare in which the vulva and vagina were completely separated by the valve over the urethral orifice ; there being no communication between the two, the vulva formed a blind sack, into which only the urethra opened.

Hekmeyer ${ }^{43}$ describes a case of closure of the os uteri in a heifer. The animal, which was three years old, and otherwise healthy, did not become pregnant, in spite of the fact that it was regularly in oestrum, and had been several times bulled. When it was slaughtered Hekmeyer found the neck of the uterus thickened and very firm; there was no os uteri, and the mucous covering of the cervix uteri was entirely absent; the horns of the uterus contained a pus-like fluid. The ovaries were small and very nodular, and the right contained some small cavities with actual pus, besides three or four remarkably large corpora lutea, while the left contained four red spots, which appeared to be formed simply of blood pigment.

Dupont ${ }^{37}$ gives as a cause of sterility in the female domesticated animals complete closure of the neck of the uterus.

Repiquet $^{44}$ in several cases observed occlusion of the os uteri by a membrane which was directed from above downwards, wider above and below than in the middle. There were thus formed two connecting orifices between uterus and vagina. 'This septum gave rise to sterility.

Gouboux $^{42}$ also observed in a mare complete closure of the os uteri by a thick membrane.

Repiquet ${ }^{22}$ cites eight cases in cows and one case in a sow in which induration of the os uteri was the cause of sterility.

Cagny ${ }^{42}$ in several cases observed stiffness and extraordinary narrowness 
of the os uteri, with consequent sterility until he dilated the os and at once allowed the animal to be served.

Dupont ${ }^{37}$ regards the growths which form on the cervix uteri after difficult parturition as a cause of infertility.

Winkler, ${ }^{45}$ in a cow which had çalved eighteen weeks previously, but which in the interval had not been in cestrum, found in the vagina an oval whitish tumour, about the size of the fist and provided with very numerous vessels. This bladder was reduced anteriorly to a string, which was no thicker than a quill and passed through the os uteri; it was filled with a yellowish brown somewhat greasy fluid, and with thirty to forty variously shaped, round and angular, yellowish brown bodies, each with an irregular surface. Soon after the bladder had been evacuated and a solution of alum injected ostrum again set in.

Heusinger ${ }^{46}$ observed that in a barren cow the os uteri possessed no opening, and was thickened and nodular.

According to Nowack, ${ }^{47}$ in a twin heifer which had been repeatedly bulled, but always without result, the vagina was remarkably narrow, its diameter measuring from scarcely $2 \mathrm{~cm}$. to $\mathrm{I} 2 \mathrm{~cm}$. ; as far as the valve over the meatus urinarius it was $7 \mathrm{~cm}$. and from there to the os uteri $5 \mathrm{~cm}$. The neck of the uterus was notably flattened, and there was a firm occlusion of the os uteri, there being thus no opening between the vagina and the uterus. The Fallopian tubes ended blindly $5 \mathrm{~cm}$. from the ovaries.

Suchanka ${ }^{1781}$ dissected a twin heifer which at three years of age had never been in cestrum, and ascertained that the vagina had a blind end, the uterus as well as the Fallopian tubes being absent. The ovaries, however, were present, had a flattened shape, and contained Graafian follicles.

Feldmann ${ }^{82}$ found that the uterus was entirely absent in a female twin calf.

In another twin calf the same author found that the uterus was rudimentary, being represented by a dense connective-tissue string without any lumen.

Kuleschow ${ }^{82}$ in one case found a uterus composed of three canals continued into a solid body; the tubes were undeveloped.

Villeroy ${ }^{68}$ in two cases found a small uterus.

André ${ }^{63}$ in a twin heifer that never came into cestrum found complete absence of the uterus.

Sanson ${ }^{8+}$ in a four years, nine months, and three-days-old Durham cow found that the right ovary was $0^{\circ} 03$ inches long, by $0^{\circ} \circ 15$ inches broad, and contained no Graafian follicles, while the left was lentll-sized. The right oviduct was as thick as a crow quill, first tortuous, and then continued in a straight line to the fundus of the vagina. The left joined the right where the latter ceased to be tortuous. Both were destitute of an opening. The vagina ended as a blind sac in part of the urethral orifice. There was no udder.

The same author ${ }^{38}$ in two very fine sterile Southdown sheep, which came early to maturity, found the following abnormalities of the sexual organs. In one of them the ovaries contained no Graafian follicles, and in the second one the ovary had three rudimentary follicles; in both the uterus was poorly developed, and the vagina formed a string perforated centrally by a canal, so that it could not accommodate the penis. It was only at the urethral orifice that the vagina was somewhat broader. In addition, the oviducts were almost occluded by melanosis.

Reynal ${ }^{78}$ regards disease and obstruction of the Fallopian tubes as a cause of sterility.

In concluding consideration of mechanical obstacles to conception in the female animal, attention may be drawn to firm closure of the os uteri. During œstrum, and hence at the time of copulation, the os uteri, which at other times is firmly closed, must dilate in order to 
make it possible for the semen to penetrate into the uterus, come into contact with the ovum, and thus lead to fertilisation. Trager ${ }^{65}$ says that the os uteri of mares examined when in ostrum will nearly always admit one, two, or three fingers. Colin also has made investigations on this point, and found that immediately after mares in œstrum had been covered the os uteri was relaxed and would admit two or three fingers. I have repeatedly found the same in mares and cows in ostrum. Indeed, in three cases of nymphomania in mares I could without difficulty introduce the whole hand through the os into the uterus, and on these grounds, and from observations made on cows constantly in ostrum, I cannot agree with Schunhoff when he asserts that, in cases of chronic cestrum, the os uteri is always firmly closed, and that this is the cause of the nymphomania.

Sterility caused by closure of the os uteri must be treated by dilatation of the latter. This need not be done at the beginning of cestrum, but may first be practised towards the end of the period, as the extrusion of the ovum, or ovulation, first takes place at this time. By introducing the forefinger and giving it a rotatory movement the os uteri is gradually dilated, until at last several fingers can be passed through the os into the uterus. If one wishes to avoid manual dilatation, one can, following the example of Delafond, use a sound of the thickness of a common catheter, or one of the instruments devised by Schunhoff. However, I regard both as superfluous, since in all the cases that I have yet treated the hand sufficed, as the following description will show.

In February 1890 a farmer, $\mathrm{Mr} \mathrm{K}$., asked me whether I possessed any means of successfully treating a mare that had had three foals, and which since the last pregnancy had been repeatedly covered without holding. I advised him to bring the mare to me as soon as she came in season, in order that I might examine her, and perhaps perform a small operation. The farmer soon did as desired, and on examination I found the os uteri stiff, hard, and firmly closed. I now tried to dilate the os, and after much trouble I succeeded in passing the forefinger of the right hand into the womb, and gradually dilated the os, until I ultimately could introduce all the five fingers. As soon as this operation was completed the mare was taken to the stallion, was covered, and became pregnant. This result induced $\mathrm{Mr} \mathrm{K}$. some time afterwards to ask me to examine three of his cows that had previously had calves, but which, in spite of the fact that they had since been repeatedly in oestrum, remained barren. Here also the examination revealed the same conditions as in the mare, and the operation again had the desired result. In a mare belonging to $\mathrm{Mr} \mathrm{D}$., I again found that the os uteri was closed, and overcame the obstacle in the manner above mentioned. Moreover, Colin, as early as $\mathrm{I} 867$, in an article in the Recueil, entitled, "De la dilatation artificielle du col de la matrice considerée comme moyen de remédies à la stérilité," and in his "Traité de Physiologie" " says that according to General Daumas, in his work, "Les chevaux et les moeurs du désert Sahara," Paris, I864, the Arabs practise this method, and he is of the opinion that they have borrowed it from Hippocrates, who describes it in his second book, the "Diseases of Women," I33. If the mare becomes pregnant after this operation the Arabs say (according to Anacker, in an extract from Daumas' work) that she had previously been mấăouda, that is, knotted.

As early as I8I6, Spor, in the fifth volume of his Veterinary Handbook, writes that the infertility of animals is incurable when there are defects of the

* Professor Johne in a footnote in the original article, says that he must, as the result of his experience, confirm the statement quoted from Schunhoff. 
internal or external genitals. " But there are many veterinary surgeons who by introducing their fingers dilate the os uteri, and thus make conception possible. In the next place something concerning the diagnosis and manipulation of the obstacles to conception. If thereby anything more is meant than rough manipulation, pointed to by no indication and justified by no experience, should surgery be able to learn nothing on the head of human infertility from veterinary surgeons?"

In the year 1839 a certain Joseph Pohler, baker and quack veterinary surgeon in Weissenbach, announced that the cause of infertility in cows was in many cases a growing together of the os uteri as the result of a previous parturition, and that to overcome this the occluded os ought to be perforated with the finger, by which means the os became dilated. In order to prevent the os from growing together again, the dilated canal was smeared with unsalted fat, or, as a simple plan, a tallow candle which had previously been softened by slightly warming it at the fire was introduced into the uterus and left there. The period of cestrum was selected as the most favourable time for performing the operation.

In the year 1846 Pantaleon Binz ${ }^{65}$ very frequently practised this operation with success.

In the year 1867 an anonymous writes (F. D.), in an article in the Recueil, entitled "De la Stérilité chez la jument," called attention to the fact that, according to André, the os uteri in animals suffering from chronic oestrum is often so firmly closed that the semen cannot penetrate into the uterus, and that a dilatation of the os uteri is necessary in order to bring about a conception.

A little later in the same year Eléouet, in an article in the same journal"Considerations sur une des causes de la stérilité chez la jument," says that he had as early as r 830 successfully treated infertility by dilatation of the os uteri.

Garrat ${ }^{66}$ also, and A. Collin ${ }^{67}$ de Bulgneville recommended dilatation of the os uteri as a remedy for barrenness.

André ${ }^{68}$. recognised spasmodic contraction of the os uteri as a cause of sterility, and combated the evil by dilatation of the os.

\section{PATHOLOGICAL CONDITIONS OF THE UTERINE MUCOUS MEMBRANE.}

\section{Disease of the Uterine Mucous Membrane as an Obstacle to Develop- ment of the Ovum.}

The mucous membrane of the uterus, as is known, is covered with a ciliated cylindrical epithelium, which is continued into the tubular sacculations of the membrane - the so-called uterine glands, and secretes a glassy alkaline fluid. At the period of oestrum changes set in which prepare the uterus for the reception of the ovum. The uterine mucosa swells up, assumes a loose character, becomes thicker, softer, and oedematous; the volume of blood in it increases, the epithelium loses its cilia, and the so-called uterine glands become wider and longer. In the mare new glands are formed between the old for the reception of the villi on the ovum, and in the cow the cotyledons destined for this purpose increase in size. The secretion of mucus increases, and the fluid secreted - the so-called uterine milk-serves at the outset for the imbedding of the ovum. But if, as in chronic endometritis, with subsequent indurative atrophy, and in hydro- or pyometra, an atrophy of the uterine mucous membrane takes place, which naturally leads to loss of the tubular diverticula of the mucosa, neither will the uterine milk necessary for the first 
nourishment of the ovum be formed, nor will the new formation of glands necessary in the mare for attaching the chorion be furnished. Further, in ruminants an atrophy of the cotyledons may result from chronic endometritis, ${ }^{48}$ which removes the possibility of the ovum being able to graft itself. The same effect is produced by tuberculosis of the uterus, which completely destroys the mucous membrane, and may penetrate into the muscularis.

Manual examination of the sexual organs, as well as the presence of muco-purulent and generally foul-smelling discharge, makes it possible to arrive at a diagnosis. In some circumstances uterine tuberculosis may certainly be diagnosed by recognising tubercle bacilli in the discharge.

In chronic endometritis, but not in tuberculosis, treatment may possibly be successful; but even in the former condition a satisfactory result can only be obtained when the alteration of the mucous membrane has not yet advanced too far. Washing out of the uterus with astringents and antiseptics is indicated.

In the case of a cow which had frequently been in oestrum, Roloff ${ }^{52}$ found tuberculous degeneration of the body and horns of the uterus. No trace of tuberculosis was observable in the tubes or ovaries, but the latter contained numerous large follicles.

Mercier ${ }^{55}$ of Edinburgh observed sterility after an attack of uterine catarrh following a difficult parturition, and found degeneration of the neck of the uterus, swelling of its vaginal portion, and ulceration of its inner surface.

\section{Particular Diseases of the Uterine MIucosa as a Chemico-Physio- logical Obstacle to Conception.}

An abnormal reaction of the mucus secreted by the lining membrane of the genital tract may give rise to sterility. The non-glandular vaginal mucous membrane secretes a small quantity of a thin fluid with a faintly acid reaction, while the uterine mucosa secretes a transparent fluid with an alkaline reaction. As a result of catarrhal processes the vaginal mucus may become strongly acid, and the alkaline reaction of the uterine mucus may also be converted into an acid one. This must be adverse to conception, since, as has already been seen (p. 227), the spermatozoa can live only with a moderately alkaline reaction, and die in acid secretions. Under normal conditions conception occurs in spite of the faintly acid reaction of the small quantity of vaginal mucus present, owing, in the first place, to the fact that the weak acidity of the vaginal mucus becomes neutralised by the addition of the alkaline uterine mucus ; and, in the second place, to the semen in the act of copulation being discharged into the fore part of the vagina (where the acid reaction has been neutralised by the alkaline mucus that flows from the uterus during cestrum), or even into the vaginal part of the uterus.

When the acidity of the vaginal mucus is too great a complete neutralisation of the uterine mucus cannot take place, and in consequence the vitality of the spermatozoa is either considerably weakened or entirely destroyed. Bouillard, according to St. Cyr and Violet, ${ }^{48}$ before the act of copulation injected I-2 glasses of water at blood temperature into the vagina. By this means the injurious effect of the acid reaction on the spermatozoa is obviated, and at the same 
time the movements of the spermatozoa are stimulated by the warm water. An almost general custom which, according to Dr Landerer, ${ }^{49}$ prevails in the island of Lesbos (the Mytilene of the present day), acts in the same way; there in mule-breeding, in order to ensure conception, warm soap solution is injected into the vagina of the asses before they are put to the stallion; it is said that after this conception nearly always occurs. Among the morbid processes which bring about the before-mentioned change in the chemical reaction of the secretion formed by the mucous membrane of the female generative organs, and thus exert an injurious action on the spermatozoa, chronic catarrh of the genital passages holds a prominent place. This may, in the first place, be induced by the presence of tumours in the vagina or uterus, which bring about changes in the secretion, and by the rapid decomposition of the mucus give rise to irritation, and change its chemical reaction. But the most frequent cause of this catarrh is retention of the placenta. The decomposition of the foetal membranes which sets in soon after parturition, aided by the action of the numerous saprophytes present, very quickly induces a chronic catarrh or putrid endometritis, which, on the one hand, as we have seen in the foregoing paragraph, renders the uterine mucous membrane unfit for the nourishment of the ovum, and, on the other hand, exerts a fatal effect on the spermatozoa and on the ovum which has reached the uterus, this effect being due to the altered chemical character of the secretion, or to poisonous properties given to it by toxins and tox-albumens produced by the arency of bacteria.

The influence which the retention of the placenta may exert on the fertility of the female animal, and through that on the profit of cattle breeding, is highly important, but unfortunately this does not appear to be fully comprehended by agriculturists and by many veterinary surgeons.

In dropsy of the uterus, and also where there is a recto-vaginal fistula, difficulty of conception may be in part explained by the changed reaction. This is the case too in the infertility which so often follows as a result of epidemic abortion. Here ought to be reckoned also the cases of non-conception after apparent recovery from an attack of infectious eruption on the genitals of cattle (Bläschenausschlage), such as has been repeatedly observed by Fenner, ${ }^{5}$ and by myself in this district; the result in these cases is attributable to the development of a catarrhal vaginitis and endometritis. As Dupont points out, that pernicious but widespread custom of taking the mare to the stallion from nine to fourteen days after foaling may set up chronic inflammation of the uterus and vagina, and thus cause sterility. In Dupont's opinion impregnation cannot occur except during cestrum, nor can it take place at the time mentioned owing to the copious secretion which washes the spermatozoa outwards.*

A diagnosis of the morbid conditions above described may be made with sufficient certainty by local examination, and by the presence of a putrid muco-purulent discharge, frequently mixed with remains of the foetal envelopes.

Treatment, which consists in washing out the cavity of the uterus with astringent and antiseptic media, is frequently successful, pro-

\footnotetext{
* Professor Johne, in a footnote to the original article, says that those who have a practical acquaintance with hoise breeding will not be able to agree with this, inasmuch as expenience contradicts the opinion expressed.
} 
vided that the evil has not yet made too great progress, and that the introduction of the irrigator tube into the uterus is still possible ; but, as is well known, great difficulty in affecting this may be experienced in cows even ten or fourteen days after parturition. The greatest importance, however, is to be attached to prevention, and above all things to the early removal of the fotal envelopes. I maintain that in every case in which the fotal envelopes do not of themselves come away during the first twenty-four hours after parturition, they ought to be removed at the end of that time by professional aid. Only in this way can the uterine catarrh, and the infertility of animals which follows on that, be prevented. I have had no experience of the method of removing the foetal membranes by washing out the uterus with warm water to which disinfectants have been added, but in most cases I have observed that in hot summer weather decomposition of the membranes sets in after two days in spite of disinfectants, and thus lays the foundation for endometritis and difficulty of conception. I hold that the only rational treatment of retained placenta, in order to prevent the occurrence of infertility, is the manual separation of the membranes, followed by thorough washing out of the uterus (by the veterinary surgeon himself), first with pure water, and thereafter with water to which lysol or some other disinfectant, or alum, has been added in proper proportions.

Moens ${ }^{50}$ found a very large medullary sarcoma of the uterus in a cow which had been four times bulled without result.

Walley ${ }^{52}$ found a fibroma of the uterus in a cow which had never shown symptoms of œstrum.

Roloff ${ }^{53}$ in a cow which had frequently been in ostrum for a quarter of a year, but had not conceived, found in the mucous membrane of the uterus numerous cysts filled with clear fluid and varying in size from a millet seed to a pea. Some cysts were present in the vaginal mucous membrane in the neighbourhood of the os uteri. The ovaries also contained cysts.

In the same way Lieutard and Rainard ${ }^{54}$ described the formation of cysts in the uterus, the former in a cow and the latter in a mare.

Schünhoff ${ }^{30}$ mentions rupture of the perineum and recto-vaginal fistula as a cause of sterility, and by way of treatment recommends that, after cleansing of the vestibulum vaginæ, and emptying of the rectum by an enema, a pledget of tow should be introduced behind the opening of the urethra, and that the hind quarters of the cow should during the act of copulation be placed in a correspondingly low position.

Näf ${ }^{56}$ says that in fluor albus, on account of the irritation of the genitals present, the cows are frequently in ostrum but difficult to get in calf.

Fuchs ${ }^{20}$ among other causes of non-conception enumerates abortion, retention of the placenta, and fluor albus.

Kummer ${ }^{57}$ also mentions that decomposing foetal membranes are apt to prevent future conception.

Giovanoli ${ }^{58}$ mentions that cows are very apt to be barren in consequence of decomposition of the foetal membranes retained in the uterus.

Trinchera ${ }^{59}$ observed sterility after epidemic abortion in consequence of the uterine catarrh excited by the bacillus.

According to Strebel, ${ }^{\mathrm{e}}$ many cows in consequence of the lochia do not for a long time come into œstrum.

Singer ${ }^{61}$ describes a case of dropsy of the uterus in a cow which had been regarded as in calf for forty-six weeks, but which exhibited no sign of approaching parturition. 


\section{Nervous Obstacles to Conception.}

Attention must be called in the first place to a condition which may be regarded as a nervous obstacle to conception, and which in many cases is the cause of infertility. Colin ${ }^{2}$ had already pointed out that the semen is pressed out as a result of severe straining on the part of the female animal tnmediately after copulation. It is probable that this pathological condition, which according to experience is most frequently met with in young very well nourished animals, depends upon a neurosis-a hyperæsthesia of the sexual nerves supplying the vulva and vagina, in consequence of which the friction of the penis during coitus sets up spastic contractions of the vaginal muscles (retractor vaginæ and levator vaginæ). A similar condition has indeed been observed in the human female, and is there designated vaginismus. It consists in a cramp-like contraction of the constrictor cuni, and is sometimes ascribable to the presence of a local affection, such as catarrh of the vagina; but it frequently occurs without any recognisable cause, and is then to be regarded as a neurosis; some consider it a symptom of general hysteria. In order to prevent the semen from being pressed out after copulation, one may, as Colin ${ }^{2}$ indicates, recommend that the animal should be exercised briskly immediately after copulation, or that cold water should be poured over the hind-quarters. From time immemorial a copious withdraval of blood immediately before coitus has had a great name as a remedy for such conditions, even in lean animals, and for the purpose it cannot be altogether condemned.*

\section{Inability to form Ova.}

The formation of the ovum presupposes the presence of healthy ovaries. If these are altogether absent, or are diseased, then the power to form ova is lost. It is a generally known fact, and for the breeder an important one, that where there are twin calves of different sexes the ovaries and other parts of the sexual apparatus of the heifer calf are congenitally deformed. The knowledge of this peculiar fact is very old. According to Numann, ${ }^{24}$ Varro and Columella were acquainted with the sterility of the female calf in twins of different sexes. Such animals, in order to distinguish them from the "vacca," or female of the ox species capable of breeding, were designated "tauræ," meaning "ox-like," since even in outward appearance they incline more to the male type. The passage in Columella ${ }^{71} \mathrm{Bk}$. VI. Ch. XXII. is as follows:--"et utique tauræ, qua locum focundarum occupant, ablegandæ, vel aratro domandæ, quoniam laboris et operis non minus quam juvenci, propter uteri sterilitatem, patientes sunt." On account of its interest, it may here be mentioned that the designation "taure" corresponds with that of "vache-bœuf," which, according to Ch. de Sourdeval, 72 in the western parts of Vendee is the customary term applied to the female unfruitful individual in cases of twin calves of different sexes; this designation in a word makes clear the nature of the object, and it is unfortunate that we in Germany have not in general use an equally short designation. The words in use with us ("Queenen" or "Zwicker ;" in English "Free martin") do

\footnotetext{
* Professor Johne in a footnote says that for many years he has in practice snocessfully treated this hyperresthesia with injections of tnorphia or lasge doses of brandy ( $\frac{1}{2}-1$ litre according to the size of the cow), which after a short stage of excitement certainly brings abont the desired depression.
} 
not so distinctly indicate what is meant, and, as far as I know, the designation that would be appropriate "Kuh-Ochse" (cow-bull) has not to my knowledge been introduced into Germany.

Numann ${ }^{70}$ himself says of these twin calves that on account of their infertility they are not suitable for breeding. It is a peculiar circumstance that when a cow gives birth to two calves of which one is a male and the other a female the latter almost always possesses incomplete, or incompletely developed, sexual organs, and is therefore unfruitful. This anomaly is not exclusively confined to twins of different sexes, for it occurs, although less frequently, in young of the same sex. Schlumpf ${ }^{73}$ makes the same observation regarding female twin calves. He expresses himself as follows:- "The female calf in twins does not give milk, and it shows no symptom of œstrum." Many other authors corroborate this, as we shall see-hereafter. Even on looking at such an animal, suspicion is excited that one has to do with a "free martin," for, in outward appearance, they resemble a bull more than a cow. According to Rueff ${ }^{14}$ they possess a badly developed udder, narrow vulva and vagina, very fleshy broad and long hind-quarters, and long ears like a bull; and on examination by the hand, or by the aid of the uterine speculum, it will frequently be found that there is a very striking development of the clitoris, and a blind ending of the vagina or a very slight development of the uterus.

In addition to the before-mentioned congenital obstacles to the formation of ova, we may have as causes anatomical changes of the ovaries in consequence of acquired disease, or physiological changes of these organs induced by nervous influences. Among the diseases of the ovaries which lead to inability to form ova, and which in order to be a cause of sterility must affect both ovaries, the inflammatory affections of these organs occupy a prominent place. For the most part we have here to consider only the chronic forms which lead to fibrous atrophy, or those which develop out of acute puerperal septic processes and lead to purulent destruction of the ovarian tissue. In the same way the destruction of the ova-forming tissue of the ovary may be brought about by tuberculous infiltration, or by tumours, which either squeeze the ovarian tissue aside by the pressure which they exert, as is the case in some follicular cysts, cystomata, dermoid cysts, fibromata, and myomata; or which cause destruction by substituting the new tissue for that of the ovary, as is the case in the malignant tumours - carcinomata, sarcomata, and melanomata.

A certain diagnosis of the above-named morbid processes can, in most cases, be made by a careful manual examination. However, it is certain that this cannot always be done, for it sometimes happens that the most minute examination leaves us in the lurch, and certain information regarding the real nature of the disease is first afforded at the post-mortem. For the practitioner it is in this connection of great importance that the pathological changes before mentioned are, during the life of the animal, often manifested by symptoms of exaggerated cestrum, or nymphomania. Since at the post-morten of animals affected in this way tuberculous disease of the ovaries has frequently been observed, the conclusion was arrived at that tuberculous degeneration of these organs ought to be regarded as the most frequent cause of nymphomania. But this opinion is inaccurate, inasmuch as tuberculosis of the ovaries is frequently found at the 
post-mortem of tuberculous cows that during life showed no sign of nymphomania. To this fact Schmidt it long ago called attention ; and recently Schünhoff ${ }^{30}$ has quite rightly pointed out how often cysts and new formations are found in the ovaries of animals in which nymphomania was not observed during life. I have myself seen several instances in which animals were so affected throughout life without my being able to discover at the post-mortem any alteration in the ovaries, or in any of the other sexual organs. I can only explain the occurrence of the symptoms of nymphomania by referring them to nervous irritation; and I am the more inclined to this since Barthelmy ${ }^{75}$ has ascertained that signs of cstrum may be exhibited even in the absence of ovaries.

Detroys ${ }^{76}$ arrived at the same result, and Imminger 77 regards nerve irritation in the sexual organs as the primary cause of nymphomania. and disease of the ovaries as a secondary result of the continual excitement and irritation of the nerves of the generative apparatus. Reynal ${ }^{78}$ had already expressed this view as a result of finding scirrhous induration of both ovaries in mares that had been the subject of chronic inflammation of these organs, and in a third case, in which there was acute inflammation of the ovaries, he found thickening not only of these organs, but also of the oviduct.

The absence of reproductive power resulting from close breeding is also to be referred to nervous influence; and, in my opinion, which is fortified by the observations of Wright and Nathusius, it may be due to diminished ovulation brought about under the influence of the nervous system, or possibly by instinctive disinclination. ${ }^{101}$

The sterility which is induced by climatic influence, such as excessive cold or excessive heat, or by change in the conditions of life, also depends on defective innervation and consequent interference with ovulation. It is well known that animals transported from a cold to a warmer region exhibit an earlier and more frequently recurring cestrum. The power of conception in animals is also greater in summer than in winter. The influence which change in the conditions of life can exert on the sexual glands is shown in Darwin's observation, that mares which are first fed in the house on dry food, and then put out to grass, do not immediately propagate. ${ }^{101}$

Nervous influence probably also explains the fact that female animals which are condemned to a constant indoor life, and which, with the view to a rich production of milk and fat, are actually stuffed with fattening food in excessive quantities, are much more frequently unfruitful than the animals accustomed to living in the fields, and leading a natural existence. Through being continually kept in damp warm buildings the animals become degenerated and anamic, while their vital energy, and therewith the energy of the individual organs, including the generative apparatus, becomes lowered; as a result of the overloading of the abdomen with masses of food, and the consequent necessity for a greater blood supply to the abdominal and pelvic organs, a condition of irritability of the generative apparatus is set up, and this leads to a disturbance of their functions. The unnatural method of keeping and feeding female breeding animals may also induce anatomical changes in the ovaries, for, besides leading to the accumulation of fat in other organs, it 
induces the deposit of fat in the sexual organs, and thus entails their inactivity. The injurious influence of artificial feeding stuffs on the reproductive powers of female animals has been recognised by Obich ${ }^{28}$ and Buittel. ${ }^{96}$

Insufficient food in respect of quantity or quality has the same effect as over-feeding. It leads to general weakness and anæemia, and also to defective irritability or complete inactivity of the sexual organs, as a result of defective blood supply, with subsequent atrophy or fatty metamorphosis. Here, therefore, we see again that the middle way is the best. Spencer ${ }^{18}$ says : "A clear proof that abundant nourishment increases the progeny and vice versa is found in mammals; we need only compare the number of young brought forth at one time by the bitch with that by the wolf or fox; while we find from six to fourteen young in the former, the latter have only five or six, occasionally seven, sometimes four or five young. The wild cat has four or five young, while the tame has five or six twice or thrice a year. The most striking difference in this respect is seen between the various breeds of tame and wild swine. Whereas the latter, according to their age, bring four, eight, or ten young into the world each year, the former have frequently seventeen in one litter, or within a period of two years generally have five litters of ten pigs each. It is further to be observed that this unusual fertility is seen in animals which are quite inactive, receiving abundant food and having no work to do. We see plainly also that among the tame mammalia themselves the well-fed are more prolific than the poorly-fed."

There ought still to be mentioned a second defect, which, especially in cattle-breeding, is very frequently brought into operation by the owners of animals, and which not rarely gives rise to infertility, viz., the putting of female animals to the male at too early an age. When one sees that heifers are put to the bull at nine months' old, and calve at a year and a half old - an age at which their own organism is not yet completely developed, and has to give up material required for the building up of its own body-it must be clear to every thinking person that the organism of the mother must hereby be weakened and impeded in its development, especially in respect of the sexual organs, and no one will wonder that in such animals the sexual desire is soon extinguished and infertility sets in. This fact was even known to Aristotle, who expresses his view on the subject as follows ${ }^{101}$ :"Early marriages produce imperfect progeny... That this is the case in the human subject as well as in other animals one sees in the weakly inhabitants of those regions where early marriages predominate." In my opinion a female animal ought not to be used for breeding purposes before its own growth is completed. But even in animals that come early to maturity this is not the case before an age of fifteen months. If this rule were followed, nymphomania would be prevented. Sanson ${ }^{97}$ ascribes nymphomania to the fact that heifers, although they come into cestrum at the age of about a year, are first put to the male at two years. He supposes that during the interval cestrum is frequently repeated, and that the now almost constant irritation of the sexual organs, in combination with the agitation of the nervous system, is the chief cause of nymphomania. But the opinion expressed by Weber ${ }^{97}$ contradicts this view of Sanson's. The former remarks, and truly, that if Sanson were right 
it would be the young cows that would suffer from nymphomania, and not, as is actually the case, the old ones.

The diagnosis of the above-described Inorbid conditions follows naturally from what has been said regarding them.

As a rule, the treatment of the sterility caused by anatomical changes in the ovaries is not successful. Zangger ${ }^{87}$ recommended crushing of the cysts from the rectum, and Zundel ${ }^{39}$ that the cysts should be punctured through the lateral wall of the abdomen with a thick trochar, with subsequent injection of irritating fluids into the tumour-an operation which certainly in veterinary practice in few cases can be carried out; only exceptionally could either of these operations lead to a cure. As a rule attention is to be directed mainly to getting such animals quickly ready for the butcher, and for this purpose, as in the case of all animals affected with other tumours or with chronic inflammation of the ovaries, spaying ought to be carried out.

On the other hand, in the cases of sterility dependent upon defects in the manner of feeding and keeping the animals, a successful result of treatment may be expected, viz., by removing the defects.*

Since in the cases just considered the symptoms of ostrum are often indistinct, it is worth while here to quote a remark by Fuchs regarding the period at which oestrum makes its appearance in cows. On this point Fuchs says :- "It is a remarkable fact that most cows (at least two-thirds) come into ostrum during the increase of the moon (from the first quarter to the fourth day of the full moon, according to Professor Numann) and this ought to be especially remembered in the management of cows in which cestrum is absent or attended with indistinct symptoms." In some respects this circumstance corresponds with what is the case in women, for, according to Strohl, ${ }^{95}$ most women menstruate in the first quarter of the moon and only a few at the time of the new or full moon.

Prahl ${ }^{79}$ mentions the case of a three-year-old heifer that did not come into cestrum, and which first took the bull after the use of aphrodisiacs. After that she increased in size, but still showed no sign of being pregnant. After slaughter it was ascertained that, with the exception of the ovaries, which were altogether absent, the sexual organs were quite normally developed.

Andouin ${ }^{80}$ in a "free martin" found the right ovary composed of a yellow fatty material, but having the form and size of an ovary; the left ovary was altogether absent.

Rueff, in a prematurely calved "free martin," found no trace of the uterus, collections of fat in place of the ovaries, and the vagina represented by a blind sac reaching as far as the urethra.

The same author ${ }^{14}$ reports that in a seven-weeks-old "free martin," the normal vagina reached only as far as the urethra, beyond which it was continued as a narrow canal to a sort of os uteri leading to a cellular body. Both uterine horns and ovaries were absent, but large collections of fat were present between the broad ligaments.

According to Rueff," in another case of a "free martin," in place of a vagina there was only a short pointed, blind canal. The ovaries had almost entirely undergone fatty degeneration.

According to the same author, ${ }^{14}$ in a four-weeks-old "free martin," the vagina ended as a blind sac, the uterus was absent, and the ovaries were in a condition of fatty degeneration.

\footnotetext{
* In a footnote Professor Johne says that in his experience the yoking of young sterile cows for light field work alongside of quiet old draught oxen has excellent results.
} 
Rueff ${ }^{14}$ observed still another case of a "free martin," in which only a narrow canal was present behind the os uteri ; this was continued towards the left, and took the place of the uterine horn on that side; on the right side only fat was present, and the ovaries appeared to be in a condition of fatty degeneration.

Brüller, ${ }^{22}$ in a two-and-a-half-years-old "free martin," which had been repeatedly bulled, but had never been in calf, found at the post-mortem that the vagina ended in the form of a blind sac, that a rudimentary band-like structure represented the uterus, and that the ovaries were absent.

Kuleschow, ${ }^{82}$ in a "free martin," found a $5 \mathrm{~cm}$. long vagina, which led into two strings that had a lumen in their first part only. These strings represented the uterus. The ovaries were undeveloped, consisting of connectivetissue and vessels, and were connected to the tubes.

In a second case the same author ${ }^{82}$ found neither uterus nor ovaries in a "free martin."

Sanson, ${ }^{83}$ in the case of a "free martin," slaughtered at the age of two years and three months, and which had been in ostrum and bulled at the age of fourteen months, found that the uterus, especially in the neighbourhood of the horns, was less developed than it normally is.

The uterine horns contained a small quantity of a milky fluid; the cotyledons were absent; the left ovary was very small, possessing no Graafian follicles but a cellular body; and the right ovary was elongated, and had undergone cystic degeneration.

In another cow Sanson ${ }^{84}$ found neither Graafian follicles nor cellular body.

Chuchu, ${ }^{87}$ in a "free martin," found a rudimentary uterine body, the uterine horns and the ovaries being absent.

Mignon ${ }^{85}$ was called to a three-year-old heifer, which had frequently shown signs of cestrum, but had not become pregnant; during the life of the animal he could not discover anything beyond an abnormally long clitoris, which measured $3 \mathrm{~cm}$. in length. At the post-mortem of the heifer Mignon found a very narrow vagina, which was scarcely $2 \mathrm{~cm}$. broad and $10 \mathrm{~cm}$. long. The cervix uteri was rudimentary, the walls of the uterus were very thin, the uterine horns were devoid of opening, the Fallopian tubes were not recognisable, and the ovaries were atrophic and devoid of ova.

Storch ${ }^{86}$ in a year old sow observed complete absence of the vagina, fusion of that part of the uterine body representing the os with the urethra, hydrometra, and cystic degeneration of the ovaries.

Zangger ${ }^{87}$ describes alterations of the ovaries by the formation of serous cists, which may have a diameter of $2-5 \mathrm{~cm}$. ; when these have been destroyed by pressure the cow may again become pregnant if put to the bull.

Kunz ${ }^{85}$ found degeneration of the ovaries, the glandular parenchyma of which had mostly disappeared, and which either appeared to be compounded of two or three considerable vesicles filled with a yellowish water (hydrops ovariæ), or showed marked atrophy and induration.

Napp ${ }^{89}$ also, in the case of a cow that was slaughtered on account of the frequent occurrence of ostrum, found hypertrophy of the ovaries, which were as large as a man's fist, and contained at their surface and in their substance vesicles of the size of a hazel nut. The vesicles (apparently Graafian follicles altered by disease) were filled with a turbid albuminous fluid. The uterus appeared very much contracted in its horns, its walls were thickened, and it contained an oily dirty fluid.

Wehenkel ${ }^{90}$ describes a fibroma of the ovary in a cow that had wrongly been supposed to be pregnant.

Bivort ${ }^{91}$ mentions a chronic epizootic inflammation of the ovaries in sows which were constantly in œstrum, but did not become pregnant. Spaying cured the condition, and showed that the ovaries were injected, and that some 
of the Graafian follicles were as large as a nut, and filled with yellowish pus, whilst others were smaller, and contained a white, somewhat turbid, fluid.

Both Dunner ${ }^{92}$ and André ${ }^{68}$ recognised inflammation, atrophy, hypertrophy, tumour formation, the formation of cysts, and tuberculous disease of the ovaries, as causes of sterility.

Bang ${ }^{93}$ describes a rare form of ovarian tumour from a mare which had been sent by Nielsen to the Veterinary College in Copenhagen. It was nearly spherical, Io or $\mathrm{I} \mathbf{\mathrm { cm }}$. in diameter, and almost entirely surrounded by a calcified capsule. When the tumour was received its contents had been almost destroyed by putrefactive decomposition and maggots, but it appeared to have had a firmish connective-tissue type of structure. The mare had been in possession of one owner between the ages of six and twenty years, and she had been covered between six and seven, but had not become pregnant. With the exception of one summer she had never been in ostrum.

Barthelmy, ${ }^{75}$ in the case of thirty-eight small pigs which had been spayed when from forty-five to sixty days old, observed that when they reached the age of three to eight months old, symptoms of cstrum were exhibited every month, just as if they had not been spayed. Barthelmy considered that the symptoms of cestrum could not have arisen unless a piece of one ovary had been left. The post-mortem of five of the animals, however, proved that this view was erroneous; for the uterine horns, Fallopian tubes, and ovaries had been removed, and only about $5 \mathrm{~cm}$. of one horn was left with the uterine body.

Bin $z^{65}$ observed the recurrence of cestrum in a mare two years after spaying, and also in several cows that had been spayed.

Knipp ${ }^{94}$ and Hartmann ${ }^{94}$ likewise observed that symptoms of chronic œstrum remained after spaying of cows affected with that condition.

Wright ${ }^{102}$ crossed a boar with a grand-daughter, etc., up to the seventh generation. The young were ultimately idiotic, showed no tendency to suck, could not walk properly, and in many cases were unfruitful. A relatively normal sow of the last of the descendants remained non-pregnant when put to the original boar, but immediately became pregnant when put with a strange boar.

Nathusius ${ }^{102}$ crossed a Yorkshire sow, whose ancestors for at least three generations had been close bred, with the uncle, which had already proved itself productive. He obtained only six, and on a second occasion five, weak pigs. He then put the sow with a boar of the black breed, which had got seven or nine young with sows of its own breed; he now got in one year thirty-nine pigs, viz., in his first litter twenty-one, and in the second eighteen.

\section{LITERATURE.}

I. Cited by Kisch, Ueber Sterilität des Weibes. Wiener med. Presse. I 873 .

2. Colin, Traité de physiologie coniparée des animaux. Tome second. Paris I 888. P. 887. 900. 903.

3. Ellenberger, Vergleichende Physiologie der Haussäugethiere. Theil II. Berlin r 892 . P. 287.309 .

4. Spinola, Handbuch der speciellen Pathologie und Therapie furr Thierärzte. Berlin 1858 . Bd. II. P. 1372 u. 1373 .

5. Fenner, Praktische Erfahrungen über den Bläschenausschlage des Rindviehs. Monatsh. f prakt. Thierheilk. von Frohner u. Kitt. Stuttgart I891. P. r98 u. 199.

6. Cited by Möller, Lehrbuch der speciellen Chirurgie für Thierärzte. Stuttgart I89r. P. 444. 31 7. 453.47 I. 464.

7. Gurlt, Ueber angeborene Harnrohrenspaltung mannlicher Thiere (Hypospadie). Magaz. f. d. ges. Thierheilk. 37. Jahrg Berlin $187 \mathrm{I}$.

8. Mittheilungen aus der thierärztlichen Praxis im Preussischen Staate von Gerlach u. Leisering. 4. Jahrg. Berlin I 857 . 
9. Repertorium der Thierheilkunde. Bd. VI. Stuttgart i 845 . P. 8

10. Cited by Hoffmann, Thierärztliche Chirurgie für praktische Thierärzte und Studirende. Stuttgart 1891. P. 634. 616. 609.

I 1. Dr Lavirotte, Sur une cause de stérilité chez la vache. Journal de méd. vétér. et de zootechnie. I 892 . P. 57 I.

I 2. The Veterinarian, reference by Schrader in Magazin f. d. ges. Thierheilk. von Gurlt u. Hertwig. 6. Jahrg. Berlin 1840. January.

I3. Temporäre Befruchtungsanomalien eines Vollbluthengstes. Observed by Dr Gillmeister. Magazin f. d. ges. Thierheilk. von Gurlt u. Hertwig. 7. Jahrg. Berlin r8.4.

I4. Thierärztliche Geburtshülfe nebst den Krankheiten der Mutterthiere und Jungen von $W$. Baumeister. 6. Aufl, vollständig neu bearbeitet von Dr A. v. Rueff. Berlin 1878 . P. I59. I52.

I5. Fogliata, Influence de l'alimentation sur la fécondité des étalons. Giorn. d'Ippol. I889; Recueil de méd. vétér. 1889. P. 758.

r6. Recueil de médecine vétérinaire 1874 , April, in the Chronique.

17. Dammann, Die Gesundheitspflege der landwirthschaftlichen Haussäugethiere. 2o Vorlesungen. I. Hälfte. Berlin I 883. P. 482.489 u. 494 .

I8. Cited by Kehrer, Beiträge zur klinischen und experimentellen Geburtsk. und Gynäkologie. II. Bd. x. Heft. Giessen I 879 . P. 94.

I9. Haussmann, Ueber das Verhalten der Samenfäden in den Geschlechtsorganen des Weibes. Berlin 1879 .

2o. Fuchs, Ursachen der Unfruchtbarkeit bei Kühen und ihre Behandlung, namentlich auch in Bezug auf den Zustand der Geschlechtsthätigkeit selbst. Archiv f. Thierheilk. Fur die Gesellschaft Schweizer Thierarzte herausgegeben von R. Zangger. Zurich 1855 . P. I I ff.

21. Fabricius, Ein Fall von Azoospermie beim Pferde. Deutsche Zeitschr. f. Thiermed. u. vergl. Pathologie. Bd. X. Leipzig i 883. P. 52.

22. Brüller, Unfruchtbarkeit bei $Z$ willingen zweierlei Geschlechts. Wochenschrift f. Thierheilk u. Viehzucht von Adam. I6. Jahrg. I 872.

23. Bulletin de la Société impériale Centrale de médecine vétérinaire. I4 février 1856 .

24. Hartmann, Fall von. Zurückbleiben der Hoden in der Bauchhöhle bei einem Eber. Oesterr. Vierteljahrsschr. f. wissensch. Veterinärkunde. 50. Jahrg. Wien 1878 .

25. Mittheilungen aus der thierärztlichen Praxis im Preussischen Staate. Neue Folge 2. Jahrg. Berlin i 877 . P. r 34 u. I35.

26. Dammann, Myxosarcoma cysticum des Hodens vom Schafbock. Zeitschrift f. prakt. Veterinarwissenschaft. Herausgegeben von Dr $\mathrm{H}$. Pütz. Bd. II. P. I 23 .

27. Gabarret, La stérilité des vaches. Revue des éléveurs nach Annales de méd. vétér. Bruxelles i 885 . P. 34.

28. Protokoll der XIX. Generalversammlung des thierärztlichens Vereins in Schwaben und Neuburg. Wochenschrift f. Thierheilk. u. Viehzucht. 9. Jahrg. I 865 .

29. Anacker, Specielle Pathologie und Therapie für Thierärzte. Hannover I879. P. 417 .

30. Schünhoff, Beiträge zur erfolgreichen Behandlung der Sterilität unter besonderer Bezugnahme auf die Stiersucht (Nymphomanie). Berliner thierärztl. Wochenschr. 29. Juni i 893.

3r. Berliner thierärztl. Wochenschr, 1889 . Nr. 45.

32. Knoll, Operation der Atresie der Scheide. Hering's Repertorium der Thierheilk. 27. Jahrg. Stuttgart I 866. P. 245.

33. Recueil de méd. vétér. pratique. p. 931. Paris 1850.

34. Goubin, Accidents consécutifs à la saillie. Recueil de méd vétér. I 878 . 
35. Knowles, Sterility of Mares. The Journal of Comparative Pathology and Therapeutics. London 1892 . March.

36. Hollman, Kleinigkeiten. Magazin f. d. ges. Thierheilk. von. Gurlt u. Hertwig. 23. Jahrg. Berlin 1857 .

37. Dupont, Infécondité et stérilité au point de vue de l'élévage, de la médecine et de la chirurgie vétérinaires. Recueil de méd. vétér. 1868 . P. $730-870$.

38. Bulletin de la Société Centrale de méd. vétér. p. 2 I5. Paris I 873.

39. Dictionnaire de médecine, de chirurgie et d'hygiène vétérinaires par Hurtrel d'Arboval. Edition entièrement refondue par A. Zundel. Tome deuxième. Paris I875. Article: Ovaires. p. 785 et Tom troisième Article testicules p. 557 u. 559.

40. Dégive, Observations pratiques. Annales de méd. vétér. 28 année. Bruxelles I 879 . octobre.

4I. Gallier, Un cas de persistance de l'hymen chez la vache. Collection séro-purulente de la matrice et du vagin.-Ponction.-Guérison. Reference in Annales de méd. vétér. Bruxelles I 88 I.

42. Conditions d'infécondité. Bulletin de la Société centr. I886. p. r75-1 $77^{\text {. }}$

43. Hekmeyer, Verschliessung des Fruchthältermundes bei einer Kalbin. Hering's Repertorium der 'Thierheilkund. I3. Jahrgang. Stuttgart I852. P. $34 \mathrm{I}$.

44. Repiquet, Cloison congénitale du Col utérin chez la vache. Journal de méd. vétér. et de zootechn. Année i 887 . Lyon. P. 240.

45. Winkler, Bildung einer Blase im Uterus. Schweizer Archiv f. Thierheilkunde. I85I. P. 340 .

46. Heusinger, Recherches de pathologie comparée. Cassel 1847 . P. 122.

47. Suchanka, Zur Zuchttauglichkeit von Zwillingskälbern. Oesterr. landwirthschaftliches Wochenbl. Nr. I6, 29. Wien 1875 .

48. Saint-Cyr et Violet, Traité d'obstétrique vétérinaire. Deuxième édition revue et considerablement augmentée. Paris r888. P. 6r. 77 u. $6 \mathrm{I}$.

49. Landerer, Mittel zur Beföderung der Befruchtung. Wochenschr. f. Thierheilk. u. Viehzucht. 5. Jahrg. ${ }^{2} 86$ I.

5o. Moens, Sarcôme encephaloide enorme de l'utérus chez une vache ; abatage du sujet, autopsie. Annal. de méd. vétér. i 89x. P. I96.

51. Walley, Uterine Fibroma, Laceration and Death by Haemorrhage. Journal of Comparative Pathology and Therapeut. 1893 . P. 83 .

52. Roloff, Tuberkeln im Uterus. Mittheilungen aus d. thierärztl. Praxis im Preussischen Staate. Neue Folge II. Berlin I877. P. I33 u. I34.

53. Idem. I 869.

54. Lieutard, Cysten der Gebärmutter mit nachfolgender Wassersucht derselben, Trächtigkeit simulirend. Hering's Repertorium der Thierheilk. 21. Jahrg. I 860 . P. 142.

55. Mercer, Entzündung, Verhärtung, Ulceration des Gebärmuttermundes und Halses als Unfruchtbarkeit bei Kuhen. Idem. 7. Jahrg. 1 $8_{4} 6$. P. 257.

56. J. J. Näf, Ueber den weissen oder Gebärmutter-Schleimfluss bei Kuhen. Schweizer Archiv f. Thierheilk. Bern I832. P. I75.

57. Kummer, Ueber Zuruckbleiben der Nachgeburt bei Kuhen. Idem. Zürich 1854 . P. I3.

58. Giovanoli, Etwas über die Retention der Eihäute. Schweizer Archiv f. Thierheilk. u. Thierzucht. I88 r. P. I8I.

59. Trinchera, Note sur l'avortement épizootique des vaches et sur la stérilité qu'en dérive. Recueil de méd. vétér. 1888 . P. $33^{6}$.

6o. Strebel, Die Lochien, ihre Bedeutung und Wichtigkeit bei den Hausthieren, besonders bei der Kuh. Zeitschr. f. Veterinärwissensch., herausgegeben von Dr H. Pütz. 5. Jahrg. Berlin 1877. P. 187. 
61. Singer, Gebärmutterwassersucht bei einer Kuh. Schweizer Archiv f. Thierheilk. I851. P. 23.

62. Träger, Ueber das Verhalten des Muttermundes bei der Begattung. Magazin f. d. ges. Thierheilk. I3. Jahrg. Berlin I847. P. 400.

63. Daumas, Das Pferd in der Sahara. From the French by Anacker. Magazin f. d. ges. Thierheilk. 28. Jahrg. Berlin 1862 .

64. Böhm, Ueber eine durch mehrfache Versuche bewahrte sehr einfache und leicht ausführbare Methode, unfruchtbaren Kühen zur Fruchtbarkeit zu verhelfen.

65. Binz, Vielfach gemachte Versuche, unfruchtbare Kühe und auch Pferde durch künstliches Oeffnen des Muttermundes zur Fruchtbarkeit zu bringen. Zeitschr.f. d. ges. Thierheilk. u. Viehzucht. Von Dieterichs, Nebel u. Vise. Bd. XIII. 1846 .

66. Garrat, Ueber die Behandlung unfruchtbarer Stuten. Hering's Repertorium d. Thierheilk. 29. Jahrg. Stuttgart I868. P. 247.

67. A. Collin de Bulgréville, De la stérilité chez la jument-Moyen de remédier à une des causes par la dilatation du col de l'utérus. Recueil de méd. vétér. I 877 . P. I52.

68. André, Observations pratiques sur la stérilité, sur le trouble des phénomènes de la génération; contribution à l'étude des maladies du produit de la conception. Annales de méd. vétér. Bruxelles $189 \circ$. P. I $25 \mathrm{ff}$.

69. Gouboux, Sur une des causes de la stérilité chez la brebis. Bulletin de la Société centr. de méd. vétér. 23. avril i 885 .

70 Numann, Ueber die Unfruchtbarkeit der unter dem Namen Zwitter (Hermaphroditen) bekannten Kühe, verglichen mit anderen Thieren, welche an Bildungsfehlern des Geschlechtsapparates leiden. Reference in the Repertorium d. Thierheilk. 5. Jahrg. Stuttgart 1844.

71. L. Junii, Moderati Columellae de re rustica Libr XII. Curante io. Matthie Gesnero Manhemii MDCCLXXXI. P. 39.

72. Ch. de Sourdeval, Die Zwillinge ungleichen Geschlechts beim Rindvieh. Reference in Oesterr. Vierteljahrsschr. f. wissenschaftl. Veterinark. Bd. XX. Wien 1863 .

73. Schlumpf, Die Löserdurre im Kanton Zug im Jahre ı800. Archiv f. Thierheilk. Für die Gesellschaft Schweizer Thierarzte herausgeg. I8I6. P. 5 I.

74. Schmidt, Auch Etwas üher die Brïllerkrankheit der Kühe. Magazin f. d. ges. Thierheilk. 2 I. Jahrg. Berlin I855. P. 20 I.

75. Barthelmy, Les chaleurs peuvent-elles se manifester chez la jeune truie après l'enlèvement complet des ovaries? Oui. Journal de méd, vétér. et de zootechnie. Lyon I 890. P. 239.

76. Detroye, De la castration de la vache considérée dans quelques cas de nymphomanie. Recueil de méd. vétér. Paris i 886. P. 555.

77. Wochenschr. f. Thierheilk. u. Viehzucht. I888. Nr. 6.

78. Reynal, Observations et réflexions pratiques sur l'ovarite aigue et chronique chez la jument. Rec. de méd. vétér. prat. Paris 1843 .

79. Mittheilungen aus der thierarztlichen Praxis im Preussischen Staate, zusammengestellt von Müller u. Roloff. I4. Jahrg. Berlin I867.

8o. Andouin, Lettre relative à la fécondité des génisses jumelles des veaux. Recueil de méd. vétér. Paris I 863.

8I. Suchanka, Zur Ursache der Unfruchtbarkeit von Zwillingskälbern. Oesterr. Vierteljahrsschr. f. wissensch. Veterinark 44. Bd. Wein 1875.

82. Feldmann u. Kuleschow, Unfruchtbarkeit der Zwillinge. Reference in Revue f. Thierheilk. u. Thierzucht von A. Koch. Bd. II. I 879.

83. Sanson, Sur la stérilité des génisses jumelles de taureaux. Bulletin de la Société centr. 22, avril I 880 .

84. Sanson, Sur un nouveau cas de malformation des organes génitaux chez 
une vache jumelles de taureau. Bulletin de la Soc, centr. to mars I 888 .

85. Mignon, Hermaphroditisme. Observation Recueillie chez M. Jules Driard, au château de Rumont.

86. Storch, Gebärmutter-Eierstockbruch, Gebärmutterwassersucht, Ovarialcysten und Mangel der Scheide bei einem erwachsenen Schwein. Oesterr. Zeitschr. f. wissensch. Veterinärk. Bd. III. Heft 4. P. I6r.

87. Schweizer Archiv f. Thierheilk. I 860; Recueil de méd. vétér. 1860 in der chronique vétér. d'Allemagne by Zundel. P. 867.

88. Kunz, Stiersucht. Schweizer Archiv f. Thierheilk. I848. P. I 25.

89. Mittheilungen aus der thierärzth. Praxis im Preussischen Staate. I 5. Jahrg. Berlin I 868 .

9०. Wehenkel, Fibrôme mou (fibroma aerolare s. laxum) de l'ovaire chez la vache. Annales de méd. vétér. I872.

9I. Bivort, Observation d'une ovarite chronique et épizootique dans l'espèce porcine. Ibidem. I868. P. 520.

92. Dunner, Stiersucht. Schweizer Archiv f. Thierheilkunde. I851. P. 20.

93. Stockfleth's Handbuch der thierärztichen Chirurgie. Uebersetzt von Chr. Steffen. 2. Theil. 4. Heft. Leipzig I 889. P. 785.

94. Mittheilungen aus der thierarztlichen Praxis im Preussischen Staate von Gerlach. 6. Jahrg. Berlin 1859 .

95. Landois, Lehrbuch der Physiologie des Menschen. 4. Aufl. Wien u. Leipzig I 885. P. 976.

96. Bericht über die XXI. Generalversammlung des thierärztlichen Vereins von Unterfranken und Aschaffenburg. Wochenschr. f. Thierheilk. u. Viehzucht. I3. Jahrg. I 869.

97. Sanson, Nymphomanie de la vache. Bulletin de la Société Centrale de méd. vétér. I 3 novembre $\mathrm{r} 890$.

98. Alois Koch, Encyklopädie der gesammtem Thierheilkunde und Thierzucht. Wien u. Leipzig. Bd. XI. P. 257. 44I. Bd. III. P. 60I.

99. Friedberger u. Fröhner, Lehrbuch der speciellen Pathologie und Therapie der Hausthiere. Stuttgart I886. P. $462 \mathrm{ff}$.

ıoo. Peuch et Toussaint, Précis de chirurgie vétérinaire. Deuxième édition entièrement refondue. Paris 1887 . Tome premier p. 66r.

го . Kisch, Die Sterilat des Weibes, ihre Ursache und ihre Behandlung. Wien u. Leipzig r886. P. 28 u. 16.

I 02. Hensen, Physiologie der Zeugung. Hermann's Handbuch der Physiologie. Bd. VI. Theil 2. Leipzig r88 r. P. I 76 u. 269.

I03. Leisering u. Müller, E. F. Gurlt's Handbuch d. vergl. Anatomie d. Haussäugethiere. 5. Aufl. Berlin 1873 . P. $5^{26}$.

ro4. Piovesan, Sarcome fibreuse de la région du fourreau sur un cheval entier in Recueil de méd. vétér. $\quad 1892$. P. 259.

105. Hobday, Case of Fibroma in the Prepuce, in the Journal of Comparative Pathology and Therapeutics. 1892 . P. 272.

106. Walley, Phimosis in a Bull, Adhesion of the Penis to the Prepuce, in The Journal of Comparative Pathology and Therapeutics i 892 . P. 73.

ro7. Verwachsung der Scheide beim Rinde in Wochenschrift für Theirheilk. und Viehzucht. I 892 . P. $428 \mathrm{ff}$. 